\title{
Pengaruh Motivasi terhadap Kinerja PT. PLN (Persero) Tamiyang Layang
}

\author{
Gusti Marliani $^{1}$, Toto Sugiarto ${ }^{2}$, Grery Varent ${ }^{3}$ \\ ${ }^{123}$ Fakultas Ekonomi, Universitas Ahmad Yani Banjarmasin \\ Email : gustimarliani@uay.ac.id
}

\begin{abstract}
This study aims to determine the effect of motivation on employee performance of PT. PLN (Persero) Tamiang Layang.The variables in this study consisted of independent variables namely Motivationor $X$ variable and dependent variable namely Employee Performance or $Y$ variable. The population in this study consistedof 48 peoplewith 11 people in managerial section and 37 people in non managerial sections. Samples were taken in non managerial sections with a total sample of 30 people. Data obtained through questionnaires were analyze dan dexamined using the SPSS program.The results of this study obtained a simple regression equation with the formula $Y=36.306+0.036 X$ where the value of $X$ is positive which indicates that Motivation has a positive effect on Employee Performance. But this is also denied by showing the value of $t_{\text {count }}=0.200$ greater $>$ than $t_{\text {table }}=2.048$ assuming that $H_{0}$ is accepted and $H_{a}$ is rejected which means that Motivation does not affect for employee performance. The coefficient of determination $\left(r^{2}\right)$ is 0.001 which in dicates that the independent variable namely Motivation affects the dependent variable or Employee Performance by $0.1 \%$ while there maining $99.9 \%$ is influenced by other factors not examined. Which means that the influence of motivation is only a little on the performance of employees of PT. PLN (Persero) Tamiang Layang.
\end{abstract}

Keywords: Motivation, Employee Performance

\section{Abstrak}

Penelitian ini bertujuan untuk mengetahui Pengaruh Motivasi terhadap Kinerja Karyawan PT. PLN (Persero) Tamiang Layang.Variabel dalam penelitian ini terdiri dari variabel bebas yaitu Motivasi atau variabel $\mathrm{X}$ dan variabel terikat yakni Kinerja Karyawan atau variabel Y. Populasi dalam penelitian ini terdiri 48 orang dengan 11 orang pada bagian manajerial dan 37 orang pada bagian non manajerial. Sampel diambil pada bagian non manajerial dengan jumlah sampel sebanyak 30 orang. Data yang diperoleh melalui kuesioner dianalisis dan di teliti menggunakan program SPSS.Hasil Penelitian ini diperoleh persamaan regresi sederhana dengan rumus $\mathrm{Y}=36,306+0,036 \mathrm{X}$ dimana nilai $\mathrm{X}$ adalah positif yang menandakan bahwa Motivasi berpengaruh positif terhadap Kinerja Karyawan. Tetapi ini dibantahkan juga dengan ditunjukkan nilai $\mathrm{t}_{\text {hitung }}=0,200$ lebih besar > dari $t_{\text {tabel }}=2,048$ dengan asumsi bahwa $\mathrm{H}_{0}$ diterima dan $\mathrm{H}_{\mathrm{a}}$ ditolak yang berarti bahwa Motivasi tidak berpengaruh terhadap Kinerja karyawan.Koefisien determinasi $\left(\mathrm{R}^{2}\right)$ sebesar 0,001 yang menunjukkan bahwa variabel independen yakni Motivasi mempengaruhi variabel dependen atau Kinerja Karyawan sebesar 0,1\% sedangkan 99,9\% sisanya dipengaruhi faktor lain yang tidak diteliti. Yang berarti pengaruh motivasi hanya sedikit terhadap kinerja dari karyawan PT. PLN (Persero) Tamiang Layang.

Kata Kunci : Motivasi, Kinerja Karyawan

(C) 2020 Jurnal Riset Inspirasi Manajemen dan Kewirausahaan

\section{PENDAHULUAN}

Dunia bisnis dan ekonomi dewasa ini memperlihatkan perkembangan yang pesat, diikuti dengan hadirnya berbagai jenis perusahaan baru yang bergerak di berbagai bidang. Untuk perusahaan, mencari posisi dan kondisi yang menguntungkan adalah tujuan utama yang harus di capai. Dengan adanya informasi dan teknologi yang sangat meningkat membuat adanya persaingan secara lokal ataupun global dengan sengit.
Sumber daya manusia adalah faktor yang sangat penting dan tidak bisa kita pisahkan dari sebuah perusahaan. Perusahaan serta karyawan merupakan dua hal yang saling memiliki keterikatan dan tidak bisa dipisahkan. Apabila karyawan berhasil membawa kemajuan bagi perusahaan, maka keuntungan yang diperoleh akan dipetik oleh perusahaan maupun karyawan. Untuk karyawan, keberhasilan merupakan pembuktian sekaligus peluang agar memenuhi kebutuhan hidup yang lebih baik lagi. Sedangkan untuk perusahaan, 
pencapaian adalah jalan menuju pertumbuhan dan perkembangan perusahaan (Mahardika 2013:1).

Salah satu aspek yang berpengaruh terhadap pencapaian perusahaan adalah motivasi kerja. Sumber Daya Alam yang ada di dalam lingkungan perusahaan harus mendapatkan motivasi kerja yang tinggi dan baik. Apabila karyawan tidak memiliki motivasi kerja maka ini dapat menghancurkan karier dari karyawan tersebut serta dapat menghambat perusahaan untuk mencapai tujuannya. Motivasi dapat diartikan sebagai sumber keinginan seseorang untuk terus maju untuk melakukan sesuatu yang baik. Motivasi bisa muncul dari diri sendiri (motivasi internal) maupun dari luar (motivasi eksternal).

Setiap manusia memiliki potensi dalam dirinya sendiri baik itu yang alami ataupun yang dilatih. Potensi dalammberperilaku atau bertindak disebut dengan kemampuan (ability), sedangkan potensi dalam menunjukkan ekspresi disebut dengan kinerja (performance). Salah satu cara yang digunakan dalam melihat perkembangan suatu organisasi adalah memalui penilaian kinerja. Hasil dari penelitian kinerja dapat menunjukkan apakah sumber daya manusia di perusahaan itu mencapai sasaran yang baik secara kualitas maupun kuantitas disertai penggunaan waktu kerja yang efektif dan efisien. Hasil kinerja ini juga menjadi acuan dan nilai suatu sumber daya manusia untuk mendapat memperoleh promosi, demosi, diklat, kompensasi, pemutusan kerja, dan sebagainya. Dengan adanya penilaian kinerja ini dapat sedikit banyak untuk memotivasi karyawan agar bekerja lebih giat lagi(Hartatik,2014).

PT. PLN (Persero) adalah Badan Usaha Milik Negara (BUMN) sebagai perusahaan monopoli dalam bidang penyediaan listrik di Indonesia. Salah satu cabangnya adalah PT. PLN (Persero) Tamiang Layang. Masyarakat pengguna listrik di kota Tamiang Layang dan sekitarnya adalah pelanggan listrik yang memanfaatkan listrik untuk berbagai macam kegiatan sehari-hari.

Tujuan orang bekerja adalah untuk mempertahankan hidupnya dan memperoleh kehidupan yang lebih baik. Namun tidak dapat dipungkiri dimana ada suatu waktu seseorang dalam bekerja untuk merasakan tidak ada semangat dan merasa letih dalam pekerjaannya. Untuk menghadirkan kembali semangat itu maka seseorang harus memiliki motivasi dalam diri yaitu motivasi internal dan faktor dari luar atau motivasi eksternal. Untuk motivasi kerja ini cenderung dari faktor eksternal karena lebih banyak hal-hal di luar keinginan diri sendiri yang mengharuskan seseorang untuk bekerja lebih rajin dan setidaknya kesadaran diri untuk bekerja yang lebih baik dari target perusahaan. Berdasarkan hasil wawancara dengan Supervisor bagian sumber daya manusia diketahui karyawan lebih termotivasi dai luar dirinya. Adapun motivasi yang diberikan oleh pihak PLN adalah sebagai mana yang ada di dalam tebel berikut :

Tabel 1 Bentuk motivasi yang diberikan PT. PLN (Persero) Tamiang Layang

\begin{tabular}{|c|c|c|}
\hline No. & Motivasi & Keterangan \\
\hline 1 & Gaji & $\begin{array}{l}\text { Gaji diberikan satu } \\
\text { kali setiap bulannya. }\end{array}$ \\
\hline 2 & $\begin{array}{l}\text { Jaminan } \\
\text { Kesehatan }\end{array}$ & $\begin{array}{l}\text { Jaminan kesehatan } \\
\text { berupa BPJS yang } \\
\text { menjamin kesehatan } \\
\text { karyawan berserta } \\
\text { keluarganya. }\end{array}$ \\
\hline 3 & Jaminan Hari Tua & $\begin{array}{l}\text { Jaminan hari tua } \\
\text { adalah pemberian dana } \\
\text { pensiun kepada } \\
\text { karyawan yang } \\
\text { berakhir masa } \\
\text { kerjanya. }\end{array}$ \\
\hline 4 & Jaminan Karier & $\begin{array}{l}\text { Karyawan dijamin } \\
\text { kariernya hingga usia } \\
63 \text { tahun }\end{array}$ \\
\hline 5 & Pelatihan & $\begin{array}{l}\text { Pelatihan karyawan } \\
\text { diberikan satu kali } \\
\text { dalam setahun }\end{array}$ \\
\hline
\end{tabular}

Sumber : data diolah di PT. PLN (Persero) Tamiang Layang 2018

\section{KAJIAN LITERATUR}

\section{Pengertian Sumber Daya Manusia}

Manajemen sumber daya manusia adalah suatu ilmu atau cara bagaimana mengatur hubungan dan peranan sumber daya (tenaga kerja) yang dimiliki oleh individu secara efisien dan efektif serta dapat digunakan secara maksimal sehingga tercapai tujuan (goal) bersama perusahaan, karyawan dan masyarakat menjadi maksimal. Manajemen sumber daya manusia didasari pada suatu konsep bahwa setiap karyawan adalah manusia bukan mesin dan bukan semata menjadi sumber daya bisnis perusahaan atau organisasi. Manajemen sumber daya manusia juga menyangkut gambaran dan penerapan sistem perencanaan, penyusunan karyawan, pengembangan karyawan, pengelolaan karier, perbaikan kinerja, kompensasi untuk karyawan dan hubungan ketenagakerjaan yang baik antar karyawan ataupun perusahaan. Manajemen sumber daya manusia melibatkan semua keputusan dan praktik manajemen yang memengaruhi secara 
langsung sumber daya manusianya. Menurut Armstrong (dalam Hartatik 2014 : 14) MSDM adalah cara pendekatan terhadap manajemen manusia yang didasarkan pada empat prinsip dasar yaitu sumber daya manusia adalah harta yang paling penting yang dimiliki dalam organisasi, sedangkan manajemen yang efektif adalah kunci dari keberhasilan suatu organisasi, keberhasilan organisasi sangat mungkin dicapai jika peraturan, kebijaksanaan dan prosedur yang berterikatan dengan manusia dari perusahaan tersebut saling berhubungan serta memberikan sumbangan terhadap pencapaian tujuan perusahaan dan perencanaan strategis, tradisi dan nilai perusahaan, suasana organisasi dan perilaku manajerial yang berasal dari kultur tersebut akan memberikan dampak yang besar terhadap hasil pencapaian yang terbaik, MSDM berhubungan dengan pembaruan yakni semua anggota organisasi terlibat dan bekerja sama untuk mencapai tujuan bersama.

Berdasarkan pengertian di atas, MSDM merupakan sebuah ilmu untuk kegiatan perencanaan, pengelolaan dan pengembangan serta potensi sumber daya manusia yang ada juga memiliki hubungan antara manusia dalam suatu organisasi ke dalam sebuah rancangan yang sistematis dan kompleks, sehingga mampu mencapai efektivitas dan efisiensi kerja dalam mencapai tujuan baik itu untuk diri sendiri, masyarakat ataupun organisasi.

\section{Fungsi Manajemen Sumber Daya Manusia}

Menurut Pandi (2018:2) Fungsi dari Manajemen yang paling penting yang berasal dari klasifikasi paling awal dari fungsi - fungsi manajerial yaitu:

\section{Planning}

Perencanaan merupakan pemilihan dan penetapan tujuan-tujuan organisasi dan juga penentuan strategi kebijaksanaan proyek dalam program prosedur metode sistem anggaran dan standar yang dibutuhkan untuk mencapai tujuan.

2. Oraganizing

Organizing atau pengorganisasian ini meliputi:

1. Penentuan sumber daya dan kegiatankegiatan yang akan dibutuhkan untuk mencapai tujuan organisasi atau perusahaan.

2. Perancangan dan pengembangan suatu organisasi atau kelompok yang akan dapat dibawa kepada hal-hal tersebut ke arah tujuannya.

3. Penugasan pada tanggung jawab tertentu

4. Pelimpahan wewenang yang diperlukan kepada individu tertentu untuk melaksanakan tugasnya.

\section{Leading}

Fungsi pengerahan adalah bagaimana membuat dan mendapatkan para karyawan melakukan apa yang diinginkan oleh perusahaan atau organisasi dan harus mereka lakukan agar tercapai tujuan dari perusahaan.

4. Staffing

Penyusunan personalia adalah penarikan (recruitment) pelatihan dan pengembangan serta penempatan dan pemberian orientasi pada karyawan dalam lingkungan kerja yang menguntungkan serta produktif.

5. Controlling

Pengawasan adalah penentuan dan penerapan cara untuk menjamin bahwa rencana telah dilaksanakan sesuai dengan yang telah di tetapkan.

Tujuan Manajemen Sumber Daya Manusia

Setiap perusahaan menetapkan tujuan tertentu yang ingin mereka capai dalam memanajemen setiap sumber daya manusianya. Menurut Cushway (dalam Sutrisno 2009:7) Tujuan MSDM meliputi:

1. Memberikan pertimbangan manajemen dalam membuat kebijakan Sumber Daya Manusia untuk memastikan organisasi memiliki pekerja yang termotivasi dan memiliki kinerja yang tinggi, memiliki pekerja yang selalu siap mengatasi masalah serta perubahan dan memenuhi kewajiban pekerjaan secara sah.

2. Membantu dalam pengembangan arah keseluruhan organisasi dan strategi khususnya yang berkaitan dengan keterkaitannya dengan SDM.

3. Menjabarkan dan menjaga semua kebijakan dan prosedur sumber daya manusia agar memungkinkan organisasi mencapai tujuannya.

4. Menangani berbagai masalah dan situasi yang sulit dalam hubungan antar karyawan untuk meyakinkan bahwa mereka tidak menghambat organisasi atau perusahaan untuk mencapai tujuannya.

5. Memberi dukungan kondisi yang akan membantu manajer bagian mencapai tujuannya.

6. Bertindak sebagai pemelihara tolak ukur organisasional dan nilai dalam MSDM.

7. Menyediakan sarana dan media komunikasi antara pekerja dan manajemen organisasi.

\section{Pengertian Kinerja}

Kinerja adalah hasil kerja yang dapat dicapai dari seseorang atau kelompok orang dalam satu perusahaan atau organisasi yang sesuai dengan wewenang dan tanggung jawab pada diri masing- 
masing dalam upaya pencapaian tujuan perusahaan secara legal, sah dan tidak bertentangan dengan norma dan etika (Pandi 2018:83). Menurut Hasibuan (dalam Yani 2012:117) kinerja adalah suatu hasil yang dicapai seseorang atau sekelompok orang dalam melaksanakan tugas yang dibebankan kepada yang didasarkan atas kemampuan, pengalaman, dan kesungguhan.

Berdasarkan pengertian tersebut di atas, kinerja adalah suatu hasil kerja yang dibebankan kepada seseorang dalam hitungan waktu tertentu secara kualitas maupun kuantitas sesuai dengan tanggung jawab yang harus dilakukan atau dikerjakan secara legal dan tidak bertentangan dengan norma dan etika.

\section{Faktor Yang Mempengaruhi Kinerja}

Faktor yang mempengaruhi kinerja antara lain (dalam Pandi 2018:86) :

1. Kemampuan, kepribadian dan minat kerja

2. Kejelasan dan penerimaan atau kejelasan peran seseorang pekerja yang merupakan taraf pengertian dan penerimaan seseorang atas tugas yang diberikan kepadanya

3. Tingkat motivasi pekerja yaitu daya energi yang mendorong, mengarahkan dan mempertahankan perilaku.

4. Kompetensi yaitu keterampilan yang dimiliki seorang pegawai.

5. Fasilitas kerja yaitu seperangkat alat dukung kelancaran operasional perusahaan.

6. Budaya kerjai yaitu perilaku kerja pegawai yang kreatif dan inovatif.

7. Kepemimpinan yaitu perilaku pemimpin dalam mengarahkan pegawai dalam bekerja.

8. Disiplin kerja yaitu aturan yang di buat oleh perusahaan agar semua pegawai ikut mematuhi agar tujuan tercapai.

Sedangkan menurut Seradmayanti (dalam Widodo 2015:133) faktor yang mempengaruhi kinerja antara lain ,Sikap dan mental (Motivasi, disiplin dan etika kerja), Pendidikan, Keterampilan, Manajemen kepemimpinan, Tingkat penghasilan, Gaji dan kesehatan, Jaminan sosial, Iklim kerja, Sarana dan prasarana, Teknologi, dan Kesempatan berprestasi.

\section{Penilaian Kinerja}

Menurut Kasmir (2016:208) Hasil kinerja yang dilakukan perusahaan akan menimbulkan berbagai bentuk kepuasan bagi karyawan. Untuk mengukur kinerja karyawan dapat digunakan beberapa indikator mengenai kriteria kinerja yakni; kualitas, kuantitas, waktu efektivitas biaya, kebutuhan akan pengawasan, dan hubungan antar perseorangan.

Adapun penjelasan dari masing-masing dimensi di atas adalah sebagai berikut :

1. Kualitas

Merupakan suatu tingkatan di mana proses atau hasil dari penyelesaian suatu kegiatan mendekati pada titik kesempurnaan. Dalam praktiknya kualitas suatu pekerjaan dapat dilihat dalam nilai tertentu

2. Kuantitas

Merupakan produksi yang dihasilkan dapat di tunjukan dalam bentuk satuan mata uang, jumlah unit atau jumlah siklus kegiatan yang diselesaikan. Pencapaian kuantitas yang diharapkan adalah jumlah yang sesuai target atau melebihi target yang telah ditetapkan.

3. Waktu

Ketepatan waktu ialah di mana kegiatan tersebut dapat diselesaikan, atau suatu hasil produksi dapat dicapai dengan batas waktu yang telah ditentukan.

4. Penekanan Biaya

Biaya dikeluarkan untuk setiap aktivitas perusahaan sudah dianggarkan sebelum aktivitas dijalankan. Jika pengeluaran biaya melebihi anggaran yang telah ditetapkan makan akan menjadi pemborosan, sehingga kinerja dianggap kurang baik demikian pula sebaliknya

5. Pengawasan

Hampir seluruh jenis pekerjaan perlu melakukan dan memerlukan pengawasan terhadap pekerjaan yang sedang berjalan. Pada dasarnya situasi dan kondisi selalu berubah dari keadaan yang baik menjadi tidak baik atau sebaliknya. Oleh karena itu, setiap aktivitas pekerjaan memerlukan pengawasan sehingga tidak melenceng dari yang telah ditetapkan. Dengan adanya pengawasan maka setiap pekerjaan akan menghasilkan kinerja yang baik.

6. Hubungan antar karyawan

Hubungan antar perseorangan akan menciptakan suasana yang nyaman dan kerja sama yang memungkinkan satu sama lain saling mendukung untuk menghasilkan aktivitas pekerjaan yang lebih baik. Hubungan antar karyawan ini merupakan perilaku kerja yang dihasilkan seorang karyawan.

Dari beberapa definisi tersebut dapat disimpulkan bahwa penilaian kinerja merupakan cara sistematis untuk mengukur kontribusi individu (karyawan) kepada organisasi tentang kekuatan dan kelemahan terkait dengan pekerjaannya. Dimensidimensi unilah yang dijadikan sebagai indikator Y 
dalam penelitian ini kecuali dimensi penekanan biaya. Hal tersebut dikarenakan penekanan biaya tidak diterapkan dalam mengukur kinerja karyawan di PT. PLN (Persero) Tamiang Layang dan selain itu penekanan biaya tidak bisa mengukur kinerja karyawan secara perseorangan.

\section{Pengertian Motivasi}

Motivasi adalah salah satu fungsi dari MSDM. Ada banyak definisi mengenai motivasi. Menurut Pandi (2018:23) Motivasi adalah keinginan yang timbul dari dalam diri seseorang atau individu karena terinspirasi, tersemangati dan terdorong untuk melakukan aktivitas dengan keikhlasan, senang hati dan sungguh-sungguh sehingga hasil dari aktivitas yang dia lakukan merupakan hasil yang baik dan berkualitas. Menurut Siagian (dalam Sutrisno, 2009:110) mengatakan bahwa motivasi adalah keadaan kejiwaan yang mendorong, menggerakkan, mengaktifkan seseorang untuk mencapai motif itulah yang mengarahkan dan menyalurkan perilaku, sikap, dan tindak seseorang yang selalu dikaitkan dengan pencapaian tujuan, baik tujuan organisasi maupun tujuan pribadi masing-masing anggota organisasi. Menurut Widodo(2015:187) motivasi adalah kekuatan di dalam diri seseorang yang mendorong perilakunya untuk melakukan tindakan.

Berdasarkan beberapa definisi atau pengertian motivasi di atas dap ditarik garis besar yaitu motivasi adalah keadaan di dalam diri atau pribadi seseorang untuk melakukan tindakan tertentu agar mencapai tujuan organisasi maupun tujuan pribadi seseorang.

\section{Faktor yang mempengaruhi motivasi}

Ada beberapa faktor yang mempengaruhi motivasi, antara lain :

1. Kebutuhan hidup

Kebutuhan untuk mempertahankan hidup, yang termasuk dalam kebutuhan ini adalah untuk memenuhi makan, minum, tempat tinggal, udara, dan sebagainya. Keinginan untuk memenuhi kebutuhan ini membuat orang berperilaku serta giat bekerja.

2. Kebutuhan masa depan

Kebutuhan akan masa depan yang baik membuat tercipta suasana tenang harmonis dan optimisme.

3. Kebutuhan harga diri

Kebutuhan akan penghargaan dan pengakuan serta penghargaan kehormatan dari perusahaan, rekan kerja dan masyarakat lingkungannya. Idealnya kehormatan timbul karena adanya prestasi yang dicapai, tetapi tidak selamanya demikian. Akan tetapi perlu diperhatikan oleh pemimpin bahwa semakin tinggi kedudukan seseorang dalam masyarakat atau posisi seseorang dalam organisasi semakin tinggi pula harga dirinya. Prestise dan status dimanifestasikan oleh banyak hal yang digunakan sebagai simbol status itu.

4. Kebutuhan pengakuan prestasi kerja

Kebutuhan atas prestasi kerja dicapai dengan menggunakan kemampuan, keterampilan dan potensi optimal untuk mencapai prestasi kerja yang sangat memuaskan. Kebutuhan ini merupakan realisasi lengkah potensi seseorang secara penuh.

Menurut Sutrisno (2009:116) Motivasi bagian dari proses psikologi dalam diri seseorang akan dipengaruhi oleh dua faktor yakni internal dan eksternal.

Faktor Internal merupakan faktor yang dapat mempengaruhi pemberian motivasi pada seseorang antara lain :

1. Keinginan untuk dapat hidup, merupakan keinginan setiap manusia misalnya makan minum dan bernafas. Keinginan untuk dapat hidup meliputi kebutuhan untuk memperoleh penghasilan yang memadai dan kondisi kerja yang aman dan nyaman.

2. Keinginan untuk memperoleh penghargaan menyebabkan seseorang mau bekerja. Dengan bekerja seseorang memperoleh status sosial, diakui, dihormati oleh orang lain maupun perusahaan dan sesama karyawan. Dengan bekerja lebih keras akan memperbaiki nasib serta merubah status sosial seseorang.

3. Keinginan untuk dapat memiliki menyebabkan seseorang untuk terdorong melakukan suatu pekerjaan. Keinginan untuk dapat memiliki sesuatu dapat mendorong seseorang untuk mau bekerja lebih keras.

4. Keinginan untuk berkuasa akan mendorong seseorang untuk bekerja. Keinginan untuk berkuasa itu dalam arti positif, tentu sebelumnya si pemilih telah melihat sendiri bahwa orang itu benar-benar mau bekerja sehingga ia pantas untuk dijadikan penguasa dalam unit organisasi atau kerja.

5. Keinginan untuk memperoleh pengakuan dapat meliputi adanya penghargaan terhadap prestasi yang didapat, adanya hubungan kerja yang harmonis antar karyawan dan pimpinan, pemimpin yang adil, serta perusahaan tempat bekerja dihargai oleh masyarakat. 
Faktor eksternal juga tidak kalah peranannya dalam memotivasi kerja seseorang. Faktor eksternal antara lai :

1. Kondisi lingkungan kerja merupakan keseluruhan sarana dan prasarana kerja yang ada di sekitar karyawan yang dapat mempengaruhi pelaksanaan pekerjaan.

2. Kompensasi yang memadai merupakan sumber penghasilan utama bagi karyawan dalam menghidupi diri berserta keluarga. Kompensasi yang memadai merupakan alat motivasi paling ampuh bagi perusahaan untuk mendorong karyawan bekerja dengan baik. Karena semakin tinggi kompensasi maka semakin tinggi pula pengaruhnya terhadap tanggung jawab dan kinerja yang akan dihasilkan karyawan.

3. Supervisi yang baik memiliki fungsi dalam memberikan arahan, membimbing kerja para karyawan dalam agar dapat melaksanakan kerja dengan baik tanpa melakukan kesalahan. Supervisi yang dekat dengan karyawan akan membuat suasana kerja menjadi bersemangat.

4. Adanya jaminan pekerjaan membuat seseorang akan bekerja sungguh-sungguh baik untuk dirinya maupun untuk perusahaan apalagi dalam pekerjaan tersebut adanya jaminan karier yang jelas bagi masa depannya.

5. Peraturan yang fleksibel. Biasanya peraturan yang bersifat melindungi dan dapat memberikan motivasi para karyawan untuk bekerja lebih baik.

6. Status serta tanggung jawab merupakan idaman setiap karyawan dalam bekerja. Mereka bukan hanya mengharapkan kompensasi semata, namun dengan menduduki jabatan yang diinginkan maka orang merasa dirinya dipercaya, diberi tanggung jawab serta wewenang untuk melakukan suatu kegiatan.

Dapat disimpulkan bahwa faktor-faktor yang mempengaruhi motivasi kerja terdiri atas motivasi kerja internal dan motivasi kerja eksternal. Berdasarkan hasil pengamatan, pemberian motivasi kerja di PT. PLN (Persero) Tamiang Layang berupa kompensasi memadai, supervisi yang baik, adanya jaminan kerja, status dan tanggung jawab dan adanya peraturan yang fleksibel. Sehingga dalam penelitian ini memakai lima bentuk motivasi kerja eksternal untuk dijadikan indikator.

\section{Tujuan Motivasi Kerja}

Pada dasarnya pemberian motivasi kerja kepada karyawan adalah untuk meningkatkan semangat karyawan. Tujuan pemberian motivasi kerja menurut Pandi (2018:26) adalah
1. Meningkatkan moral dan kepuasan kerja karyawan.

2. Meningkatkan produktivitas kerja karyawan.

3. Mempertahankan kestabilan karyawan perusahaan.

4. Meningkatkan kedisiplinan karyawan.

5. Mengefektifkan pengadaan karyawan.

6. Menciptakan suasana dan hubungan kerja yang baik.

7. Meningkatkan loyalitas, kreativitas, dan prestasi karyawan.

8. Meningkatkan tingkat kesejahteraan karyawan.

9. Mempertinggi rasa tanggung jawab karyawan terhadap tugas-tugasnya.

10. Meningkatkan efisiensi penggunaan alat-alat dan bahan baku.

\section{Teori Motivasi Kerja}

Teori motivasi kerja dapat memudahkan manajemen perusahaan dalam menggerakkan serta mendorong dalam menjalankan tugas yang di bebankan kepada karyawan. Menurut Sutrisno (2009:122) berikut merupakan penjelasan motivasi kerja karyawan :

1. Teori Motivasi Konvensional. Teori motivasi yang dinyatakan oleh Frederick Winslow Taylor adalah memandang bahwa keinginan seseorang agar terpenuhi kebutuhannya membuat orang mau bekerja keras. Seseorang akan berbuat atau tidak berbuat tergantung oleh ada atau tidaknya imbalan yang di peroleh oleh yang bersangkutan.

2. Teori Motivasi Hierarki. Teori motivasi yang di dinyatakan oleh Abraham Maslow ini memaparkan bahwa kebutuhan manusia dapat diklasifikasikan ke dalam 5 (lima) tataran sebagai berikut :

a. Physiologicalneedsatau kebutuhan Fisik non Biologis

Kebutuhan untuk mempertahankan hidup dari kematian, kebutuhan ini berupa kebutuhan untuk makan minum tempat tinggal serta pakaian yang harus dipenuhi oleh seseorang dalam upaya mempertahankan hidupnya dari haus, lapar, panas, dingin dan berbagai hal utama lainya.

b. Safetyandsecurityneedatau kebutuhan keselamatan dan keamanan

Kebutuhan ini dapat terpenuhi apabila kebutuhan dasar terpenuhi sehingga individu akan berusaha memenuhi kebutuhan tingkat yang lebih lagi yaitu keselamatan dan keamanan diri juga harta yang dimilikinya.

c. Affiliantionoracceptenceneedsatau kebutuhan sosial 
Kebutuhan ini merupakan kebutuhan agar bisa hidup bersama dengan orang lain, kebutuhan ini dapat terpenuhi hanya bersama masyarakat karena memang orang lainlah yang dapat memenuhinya. Misalkan kebutuhan untuk disayang, dicintai, dihormati dan diakui di dalam masyarakat.

d. Estemor status needsatau kebutuhan akan penghargaan

individu pasti memerlukan penghargaan diri dan dihormati dari lingkungannya, semakin tinggi statusnya maka diikuti juga dengan semakin tingginya kebutuhan akan kehormatan diri yang bersangkutan.

e. SelfActualizationatau aktualisasi diri

Kebutuhan akan aktualisasi diri adalah tingkat kebutuhan yang tertinggi. Untuk memenuhi kebutuhan tertinggi ini biasanya setiap individu akan bertindak bukan atas dorongan orang lain tetapi karena kesadaran dan keinginan dirinya sendiri. Hal tersebut terlihat pada kegiatan pengembangan kemampuan diri memalui berbagai cara seperti mengikuti diskusi, seminar, pendidikan lebih lanjut dan sebagainya.

\section{Teori Model dan faktor}

Menurut Frederic Hezberg teori pemeliharaan motivasi ada dua faktor yang mempengaruhi kondisi pekerjaan seseorang :

1. Faktor motivasi disebut juga motivator merupakan faktor untuk mendorong seseorang untuk berprestasi yang bersumber dari dalam diri orang yang bersangkutan. Faktor motivasi ini mencakup kepuasan kerja, prestasi yang diperoleh, peluang untuk melangkah kedepan, pengakuan dari orang lain, kesempatan pengembangan karier, dan tanggung jawab.

2. Faktor Pemeliharaan disebut juga hygienfactor merupakan faktor yang berkaitan tentang pemenuhan kebutuhan untuk memelihara keberadaan karyawan atau pegawai sebagaimana manusia, pemeliharaan ketenteraman, dan juga kesehatan. Faktor pemeliharaan ini meliputi gaji, keadaan kerja fisik, kepastian pekerjaan, sistem kerja yang menyenangkan dan sebagainya.

Berdasarkan beberapa teori motivasi di atas dapat disimpulkan bahwa tidak lah cukup untuk memenuhi kebutuhan makan dan minum saja. Orang-orang juga membutuhkan kepuasan dalam kebutuhan psikologis dan biologisnya. Semakin tinggi status seseorang dalam organisasi maka pemenuhan kebutuhan jasmani akan semakin meningkat. Bila seseorang memiliki keahlian untuk memperoleh kepuasan materi maupun non materi maka akan semakin bersemangat seseorang dalam bekerja dengan cara menggunakan semua kemampuan yang dimilikinya.

\section{Hubungan Motivasi Kerja Dengan Kinerja Karyawan}

Kasmir (2016 : 190) menyatakan bahwa jika karyawan memiliki dorongan yang kuat dari dalam dirinya atau dorongan dari luar dirinya misalnya dari pihak perusahaan, maka karyawan akan terangsang dan terdorong untuk melakukan sesuatu dengan baik. Sedangkan menurut Robbins (dalam Aruan 2013:3) menyatakan bahwa kinerja individu di tempat kerja tidak hanya bergantung dari kemampuannya saja, karena hal ini tidak berarti apa-apa jika dalam diri karyawan tidak ada keinginan atau motivasi dalam bekerja dengan baik pula. Pada akhirnya dorongan atau rangsangan baik itu dari dalam maupun dari luar, seseorang akan menciptakan kinerja yang lebih baik. Demikian pula apabila tidak adanya pemicu untuk melakukan pekerjaan maka karyawan tersebut akan menghasilkan kinerja yang kurang biak dan menurunkan kinerja karyawan tersebut. Dengan demikian dapat dikatakan bahwa motivasi memiliki pengaruh terhadap kinerja karyawan. Semakin mendapatkan motivasi seseorang untuk melakukan pekerjaan maka hasil yang akan di dapat juga akan ikut meningkat, sedangkan yang tidak termotivasi maka hasilnya pun akan ikut menurun.

\section{METODE PENELITIAN}

\section{Skala Pengukuran}

Skala pengukuran dalam penelitian ini yaitu skala Likert. Menurut Sugiyono (2015:168) skala Likert dipergunakan untuk mengukur dari sikap, pendapat, dan persepsi oleh seseorang atau sekelompok orang tentang fenomena sosial yang terjadi. Dalam penelitian fenomena sosial ini telah ditetapkan secara spesifik oleh peneliti yang nantinya disebut sebagai variabel penelitian. Dengan sekala likert, variabel yang akan diukur dijabarkan dengan indikator-indikator variabel. Kemudian indikator tersebut dijadikan sebagai titik tolak untuk menyusun item-item instrumen yang dapat berupa pertanyaan atau pernyataan. Pengukuran dilakukan dalam penelitian ini menggunakan sekala Likert yang telah dimodifikasi dari 5 (lima) kategori jawaban menjadi 4 (empat) kategori jawaban. berikut :

Bentuk pilihan ganda diberi skor sebagai

$\begin{array}{ll}\text { Sangat Setuju (SS) } & \text { : diberi skor } 4 \\ \text { Setuju (S) } & \text { : diberi skor } 3 \\ \text { Tidak Setuju (TS) } & \text { : diberi skor } 2\end{array}$


Sangat Tidak Setuju (STS) : diberi skor 1

Memodifikasi skala likert dari 5 (lima) kategori jawaban menjadi 4 (empat) kategori jawaban dengan meniadakan kategori kategori jawaban yang ditengah berdasarkan alasan sebagai berikut Hadi (1991:20) :

1. Kategori ditengah mempunyai arti ganda. Biasanya diartikan belum dapat memutuskan sesuatu atau memberi jawaban, atau bahkan ragu-ragu.

2. Tersedianya jawaban ditengah akan menimbulkan kecenderungan menjawab ke tengah terutama bagi mereka yang ragu atas arah kecenderungan jawaban, ke arah setuju atau tidak setuju.

3. Maksud kategori menjadi 4 jawaban adalah untuk melihat kecenderungan jawaban responden ke arah setuju atau tidak setuju. Jika disediakan 5 jawaban akan menghilangkan banyak data penelitian sehingga mengurangi bentuknya informasi yang dapat diperoleh dari para responden.

Penelitian ini menggunakan skala Likert yang telah dimodifikasi menjadi empat jawaban dengan alasan dalam penelitian ini peneliti ingin memperoleh informasi dari responden ke arah setuju atau tidak setuju, dengan demikian tidak mengurangi informasi yang diperoleh dari para responden.

\section{Uji Instrumen Data}

\section{Uji Validitas}

Uji validitas data dapat dilakukan dengan menghitung korelasi antara masing-masing pertanyanya pengamatan. Menurut Sekaran (dalam Sarjono dan Jaliannita, 2013:35) validitas adalah bukti bahwa instrumen, teknik dan proses yang digunakan untuk mengukur sebuah konsep benar-benar mengukur konsep yang dimaksudkan. Uji validitas bertujuan untuk mengukur sebuah konsep yang dimaksudkan. Dalam penelitian ini menggunakan metodeCorrected item total corelation. Suatu variabel dikatakan valid apabila variabel tersebut memberikan nilai korelasi minimal 0,30. Menurut Azwar (dalam Priyatno 2012:184) semua item yang mencapai nilai korelasi minimal 0,30 daya pembedanya itu di anggap memuaskan sedangkan item yang memiliki nilai koefisien di bawah 0,30 dianggap tidak valid. Semua pengujian validitas dalam penelitian ini dilakukan dengan program SPSS.

\section{Uji Reliabilitas}

Selain di haruskan valid, instrumen juga harus reliabel atau dapat diandalkan. Sekaran (dalam Sarjono dan Juianita, 2013:23) Menyatakan bahwa keandalan suatu pengukuran menunjukkan sejauh mana pengukuran tersebut dilakukan tanpa bias (bebas dari kesalahan/errorfree). Uji reliabilitas digunakan untuk mengukur tentang suatu kuesioner yang merupakan indikator dari variabel. Kuesioner dikatakan reliabel apabila jawaban seorang sampel terhadap pertanyaan bersifat konsisten atau stabil dari waktu ke waktu. Teknik ini menggunakan metode cronbachalpha. Sebuah variabel dikatakan reliabel jika nilai cronbachalpha> 0,60 (sarjono dan Julianita, 2013:45) Pengujian ini menggunakan program SPSS.

\section{Tahap Analisis Data}

Tahapan dalam analisis data pada penelitian ini adalah sebagai berikut :

1. Analisis Statistik Deskriptif

Analisa statistik deskriptif ini dapat digunakan untuk memberikan penjelasan dalam penelitian lanjutan untuk memberikan hasil yang lebih baik terhadap analisa regresi.

2. Regresi Linear Sederhana

Menurut Priyatno (2012:117) analisis regresi sederhana digunakan untuk mengukur besarnya pengaruh dari suatu variabel independen terhadap satu variabel dependen. Analisis regresi linear sederhana dipergunakan untuk mengetahui dari pengaruh variabel motivasi kerja $(\mathrm{X})$ terhadap variabel kinerja karyawan (Y) dengan rumus sebagai berikut :

Keterangan :

$$
\mathbf{Y}=\mathbf{a}+\mathbf{b x}
$$

$\mathrm{Y}=$ Nilai variabel dependen, yaitu kinerja

$\mathrm{a}=$ Nilai $\mathrm{Y}$, bila $\mathrm{X}=0$

$\mathrm{b}=$ koefisien regresi, $\mathrm{b}$ positif $(+)=$ naik dan bila $\mathrm{b}$ minus $(-)=$ turun

$\mathrm{x}=$ nilai variabel independen, yaitu motivasi kerja

\section{Pengujian Hipotesis}

Uji hipotesis digunakan bertujuan untuk mengetahui signifikansi dari masing-masing variabel bebas terhadap variabel terikat yang terdapat dalam model uji hipotesis yang dilakukan adalah:

1. Uji t

Uji t digunakan untuk mengetahui apakah variabel independen berpengaruh secara signifikan atau tidak terhadap variabel dependen (Priyatno, 2012:125). Pengujian dilakukan menggunakan tingkat signifikansi 
5\%. Dasar pengambilan keputusan adalah sebagai berikut :

- $\mathrm{H}_{0}$ ditolak dan $\mathrm{H}_{\mathrm{a}}$ diterima apabila $\mathrm{T}_{\text {hitung }}>\mathrm{T}_{\text {tabel }}$ (motivasi kerja berpengaruh terhadap kinerja karyawan)

- $\mathrm{H}_{0}$ diterima dan $\mathrm{H}_{\mathrm{a}}$ ditolak apabila $\mathrm{T}_{\text {hitung }}<\mathrm{T}_{\text {tabel }}$ (motivasi kerja tidak berpengaruh terhadap kinerja karyawan)

2. Uji R Square (Koefisien Determinasi)

Koefisien determinasi merupakan data untuk mengetahui seberapa besar pengaruh langsung variabel bebas yang semakin dekat hubungannya dengan variabel terikat dalam jumlah persen atau dapat dikatakan bahwa penggunaan model tersebut bisa dibenarkan. Koefisien determinasi $\left(\mathrm{R}^{2}\right)$ dapat diperoleh suatu nilai untuk mengukur besarnya sumbangan dari beberapa variabel $\mathrm{X}$ terhadap variasi naik turunnya variabel $\mathrm{Y}$ (Priyatno 2010:24)

\section{Tahap Penarikan Kesimpulan}

Tahap penarikan kesimpulan merupakan tahap akhir dalam sebuah penelitian. Penarikan kesimpulan dalam penelitian merupakan pemikiran kesimpulan dari data dan informasi yang telah di analisis untuk memecahkan permasalahan yang diteliti. Penarikan kesimpulan menggunakan metode induktif, yaitu penarikan kesimpulan berdasarkan hal-hal yang bersifat khusus terhadap hal-hal yang bersifat umum artinya peneliti ingin meneliti sampel yang dapat mewakili keseluruhan populasi karyawan PT. PLN (Persero) Tamiang Layang.

\section{HASIL PENELITIAN DAN PEMBAHASAN}

\section{Analisis Statistik Deskriptif}

Dalam sebuah penelitian deskriptif data itu penting untuk memberikan gambaran data yang diteliti. Di samping itu, dengan adanya deskriptif data ini, para pembaca akan lebih mudah untuk mengetahui paparan data dalam sebuah penelitian secara lebih terperinci dan jelas. Dan akan dijelaskan pada tabel 4.5 berikut.

\section{Tabel 4.5}

\section{Statistik deskriptif variabel Motivasi $(\mathrm{X})$}

\begin{tabular}{cccccc}
\hline & \multicolumn{2}{c}{ N } & \multicolumn{2}{c}{ Skewness } & \multicolumn{2}{c}{ Kurtosis } \\
\cline { 2 - 6 } & Statistic & Statistic & $\begin{array}{c}\text { Std. } \\
\text { Error }\end{array}$ & Statistic & $\begin{array}{c}\text { Std. } \\
\text { Error }\end{array}$ \\
\hline JumlahX & 30 & 0,238 & 0,427 & -0.069 & 0,833 \\
\hline $\begin{array}{c}\text { Valid N } \\
\text { (listwise) }\end{array}$ & 30 & & & & \\
\hline Sumber & Data diolah dari data SPSS pada lampiran
\end{tabular}

Tampilan tabel diatas menunjukkan jumlah responden $(\mathrm{N})$ ada 30 orang, dari 30 responden ini pengaruh motivasi terkecil adalah 28 dan yang terbesar adalah adalah 38. Nilai Range antara yang terkecil dan terbesar dari motivasi yang didapat adalah 10 dan nilai keseluruhan adalah 984. Ratarata nilai dari ke-30 responden ini adalah 32,80 dengan standar deviasi sebesar 2,384.

Skewnessdan Kurtosis merupakan ukuran untuk melihat apakah data dari Motivasi tersampaikan secara normal atau tidak kepada karyawan. Skewness mengukur kemencengan dari data. Sementara Kurtosis mengukur puncak dari distribusi motivasi yang didapatkan karyawan. Data dikatakan didistribusikan secara normal atau tidak apabila nilai Skewnessdan Kurtosis mendekati nol. Hasil dari output SPSS memberikan nilai Skewnessdan Kurtosis masing-masing 0,234 dan $-0,069$, sehingga dapat disimpulkan bahwa motivasi didistribusikan secara normal kepada karyawan.

Tabel 4.6

Statistik deskriptif variabel Kinerja Karyawan (Y)

\begin{tabular}{cccccc}
\hline & N & \multicolumn{2}{c}{ Skewness } & \multicolumn{2}{c}{ Kurtosis } \\
\cline { 2 - 6 } & Statistic & Statistic & $\begin{array}{c}\text { Std. } \\
\text { Error }\end{array}$ & Statistic & $\begin{array}{c}\text { Std. } \\
\text { Error }\end{array}$ \\
\hline JumlahY & 30 & $-0,282$ & 0,427 & $-0,892$ & 0,833 \\
\hline $\begin{array}{c}\text { Valid N } \\
\text { (listwise) }\end{array}$ & 30 & & & & \\
\hline Sumber : Data diolah dari data SPSS pada lampiran
\end{tabular}

Sumber : Data diolah dari data SPSS pada lampiran

Tampilan tabel diatas menunjukkan jumlah responden $(\mathrm{N})$ ada 30 orang, dari 30 responden ini nilai kinerja terkecil adalah 33 dan yang terbesar adalah adalah 41. Nilai Range antara yang terkecil dan terbesar dari kinerja yang didapat adalah 8 dan nilai keseluruhan adalah 1125 . Rata-rata nilai dari ke-30 responden ini adalah 37,50 dengan standar deviasi sebesar 2,301

Hasil dari output SPSS memberikan nilai Skewnessdan Kurtosis masing-masing -0,282 dan 0,892 sehingga dapat disimpulkan bahwa kinerja didistribusikan secara normal oleh karyawan.

\section{Regresi Linear Sederhana}

Secara umum rumus persamaan regresi linear sederhana adalah :

$$
\mathbf{Y}=\mathbf{a}+\mathbf{b X}
$$

Sumber : Data diolah dari data SPSS pada lampiran 
Sementara untuk mengetahui nilai koefisien regresi tersebut kita dapat berpedoman pada output yang berada pada tabel koefisien berikut.

Tabel 4.7

Tabel Koefisien Linear Sederhana

\begin{tabular}{|c|c|c|c|c|c|}
\hline \multicolumn{6}{|c|}{ Coefficients $^{\mathrm{a}}$} \\
\hline \multirow[t]{2}{*}{ Model } & \multicolumn{2}{|c|}{$\begin{array}{l}\text { Unstandardized } \\
\text { Coefficients }\end{array}$} & \multirow{2}{*}{$\begin{array}{c}\begin{array}{c}\text { Standardized } \\
\text { Coefficients }\end{array} \\
\text { Beta } \\
\end{array}$} & \multirow[t]{2}{*}{$\mathrm{t}$} & \multirow[t]{2}{*}{ Sig. } \\
\hline & B & Std. Error & & & \\
\hline (Constant) & 36,306 & 5,993 & & 6,058 & 0,000 \\
\hline Motivasi & 0,036 & 0,182 & 0,038 & 0,200 & 0,843 \\
\hline
\end{tabular}

Sumber : Data diolah dari data SPSS pada lampiran

Angka konstan dari Unstandardized Coefficientspada tabel tersebut adalah 36,306. Anggka ini merupakan angka konstan yang mempunyai arti bahwa jika tidak ada Motivasi (X) maka nilai konsisten Kinerja Karyawan (Y) adalah sebesar 36,306. Angka koefisien regresi nilainya adalah sebesar 0,036. Angka ini mengandung arti bahwa setiap penambahan 1(satu) tingkat Motivasi (X), maka Kinerja akan meningkat sebesar 0,036.

Karena nilai koefisien regresi bernilai positif $(+)$, maka dengan demikian dapat dikatakan bahwa Motivasi (+) berpengaruh positif terhadap Kinerja Karyawan (Y). Sehingga didapatkan Regresi lineranya adalah :

$$
\mathrm{Y}=36,306+0,036 \mathrm{X}
$$

\section{Uji Hipotesis}

Uji hipotesis atau uji pengaruh berfungsi untuk mengetahui apakah koefisien regresi tersebut signifikan atau tidak. Untuk memastikan apakah koefisien regresi tersebut signifikan atau tidak dilakukanlah uji hipotesis dengan cara membandingkan nilai signifikansi (Sig.) dengan probabilitas 0,05 atau dengan cara lain yakni membandingkan nilai $\mathrm{t}$ hitung dengan $\mathrm{t}$ tabel. Adapun yang menjadi dasar dari pengambilan keputusan ini adalah :

- Jika nilai signifikansi (Sig.) lebih kecil < dari probabilitas 0,05 maka ada pengaruh Motivasi (X) terhadap Kinerja Karyawan (Y).

- Sebaliknya jika nilai signifikansi (Sig.) lebih besar > dari nilai probabilitas 0,05 maka tidak ada pengaruh Motivasi (X) terhadap Kinerja Karyawan (Y).

Berdasarkan output pada tabel 4.7 diketahui nilai signifikansi (Sig.) sebesar 0,843 lebih besar > dari nilai probabilitas 0,05 sehingga dapat disimpulkan bahwa $\mathrm{H}_{0}$ diterima dan $\mathrm{H}_{\mathrm{a}}$ ditolak, yang berarti bahwa "Motivasi (X) tidak berpengaruh terhadap Kinerja Karyawan (Y)"

\section{Hipotesis Uji t}

Dasar pengambilan keputusan dalam uji t ini adalah sebagai berikut:

- Jika nilai $t_{\text {hitung }}$ lebih besar $>$ dari $t_{\text {tabel }}$ maka ada pengaruh Motivasi (X) terhadap Kinerja Karyawan (Y)

- Sebaliknya, Jika nilai $t_{\text {hitung }}$ lebih kecil $<\mathrm{t}_{\text {tabel }}$ maka tidak ada pengaruh Motivasi (X) terhadap Kinerja Karyawan (Y)

Berdasarkan outputspss pada tabel 4.10 diatas nilai $t_{\text {hitung }}$ sebesar 0,200 . Karena nilai $t_{\text {hitung }}$ sudah ditemukan, maka langkah selanjutnya akan mencari nilai $\mathrm{t}_{\text {tabel }}$. Adapun rumus dalam menurut $\mathrm{t}$ tabel adalah :

Nilai a / $2=0,05 / 2=0,025$

Derajat kebebasan $(\mathrm{df})=\mathrm{n}-2=30-2=28$

Nilai 0,$025 ; 28$ kemudian diterapkan pada distribusi nilai $\mathrm{t}_{\text {tabel }}$ maka didapat nilai besaran 2,048 . Karena nilai $t_{\text {hitung }}$ sebesar 0,200 lebih kecil $<$ dari $\mathrm{t}_{\text {tabel }}$ 2,048 maka dapat disimpulkan bahwa $\mathrm{H}_{0}$ diterima dan $\mathrm{H}_{\mathrm{a}}$ ditolak, yang berarti bahwa "Motivasi (X) tidak berpengaruh terhadap Kinerja Karyawan (Y)".

\section{Hipotesis uji $\mathbf{R}^{2}$}

Untuk mengetahui besaran pengaruh Motivasi (X) terhadap Kinerja Karyawan (Y) dalam analisis ini kita dapat berpedoman pada nilai $\mathrm{R}$ Square atau $\mathrm{R}^{2}$ yang terdapat pada output SPSS pada tabel 4.8 berikut ini:

Tabel 4.8

Tabel Uji $\mathbf{R}^{2}$

\begin{tabular}{|c|c|c|c|c|}
\hline \multicolumn{5}{|c|}{ Model Summary } \\
\hline Model & $\mathrm{R}$ & R Square & $\begin{array}{l}\text { Adjusted } \\
\text { R Square }\end{array}$ & $\begin{array}{l}\text { Std. } \\
\text { ErroroftheEstimate }\end{array}$ \\
\hline 1 &, $038^{\mathrm{a}}$ & 0,001 & 0,034 & 2,340 \\
\hline
\end{tabular}

Sumber : Data diolah dari data SPSS pada lampiran

Dari output diatas diketahui bahwa nilai $\mathrm{R}$ Square sebesar 0,001. Nilai ini mengandung arti bahwa pengaruh Motivasi (X) terhadap Kinerja Karyawan adalah sebesar 0,1 \% sedangkan 99,9\% kinerja karyawan dipengaruhi oleh variabel yang lain yang tidak diteliti. 


\section{PENUTUP}

\section{Kesimpulan}

Berdasarkan hasil penelitian pada karyawan PT. PLN (Persero) Tamiang Layang dan hasil analisis data tentang pengaruh motivasi terhadap kinerja karyawan PT. PLN (Persero) Tamiang Layang maka dapat diperoleh kesimpulan bahwa motivasi tidak berpengaruh signifikan terhadap kinerja karyawan PT. PLN (Persero) Tamiang Layang. Dengan didapatkannya persamaan $\mathrm{Y}=$ $36,306+0,036 \mathrm{X}$ menunjukkan bahwa dengan adanya pemberian motivasi maka kinerja juga akan semakin meningkat walaupun kinerja sudah memiliki nilai konstan yang cukup tinggi dan pengaruh motivasi sangat terasa sedikit bahkan hampir tidak mempengaruhi kinerja karyawan. Pengaruh motivasi terhadap kinerja karyawan berpengaruh sangat kecil dengan angka persentase sebesar $0,1 \%$.

\section{DAFTAR PUSTAKA}

Afandi, P. 2018 Manajemen Sumber Daya Manusia; Teori Konsep dan Indikator. Cetakan Pertama. Riau : ZanafaPublishing.

Alimudin, I. K. 2012 Pengaruh Motivasi Terhadap Produktivitas Kerja Karyawan Pada PT. Telkom Indonesia, Tbk Cabang Makasar. Skripsi. Makasar : Universitas Hasanuddin.

Aruan, D. A. 2013. Pengaruh Pelatihan Kerja dan Motivasi terhadap Kinerja Karyawan PT. Sucofindo (Persero) Surabaya. Vil 1 No.2.

Bungin, B. 2005. Metode Penelitian Kuantitatif. Jakarta : Kencana Prenadamedia Group.

. 2014. Metode Penelitian Kuantitatif. Jakarta : Kencana Prenadamedia Group.

Djarwanto, P. S. 2010. Metode penelitian, Cetakan Pertama Edisi Pertama. Jogjakarta : BPFE UGM.

Hadi, S. 1991. Prosedur Penelitian Suatu Pendekatan Praktis Edisi Revisi IV. Jakarta : PT. Rineka Cipta.

Hartatik, I. P. 2014. Buku praktis mengembangkan SDM. Cetakan Pertama. Jogjakarta : Laksana.

Kasmir, S. M. 2016 Manajemen Sumber Daya Manusia (Teori dan Praktik). Jakarta : PT. Raja Grafindo Persada.
Mahardika Rangga, D. H. 2013. Pengaruh Motivasi Kerja terhadap Kinerja Karyawan(Survei Karyawan PT. Axa Financial Indonesia Sales Office Malang). Jurnal Administrasi Bisnis. Fakultas Ilmu Administrasi Universitas Brawijaya.

Novitasari, L. 2016. Pengaruh Budaya Perusahaan terhadap Kinerja Karyawan di Syafia Plaza Jember. Skripsi. Jember : Universitas Jember.

Priyatano, D. 2012. Paham Analisis Data Statistik Dengan SPSS 20. Yogyakarta : CV. Andi Offset.2

Sarjono. H. J. 2013. SPSS VS LISREL. Jakarta : Salemba Empat.

Setiawan, K. C. 2015. Pengaruh Motivasi Kerja Terhadap Kinerja Karyawan Level Pelaksana Di Divisi Operasi PT. Pusri Palembang. Jurnal Psikologi Islami. Vol 1 No.2.

Sugiyono. 2015. Metode Penelitian Manajemen. Cetakan Keempat. Bandung : Alfabeta.

Sutrisno, E. 2009. Manajemen Sumber Daya Manusia, Jakarta : Kencana Prenadamedia Group.

Widodo, S. E. 2015. Manajemen Pengembangan Sumber Daya Manusia. Cetakan Kedua. Jogjakarta : Pustaka Pelajar.

Yani, H. M. 2012. Manajemen Sumber Daya Manusia. Jakarta : Mitra Wacana Media.

\section{Profil Penulis}

1. Gusti Marliani, S.E., M.E, Dosen Fakultas Ekonomi universitas Achmad Yani Banjarmasin.

Email : gustimarliani@uay.ac.id 